\title{
KRITIK TERHADAP BANGSA KOLONIAL MELALUI TOKOH UTAMA NOVEL STUDENT HIDJO KARYA MARCO KARTODIKROMO DAN SALAH ASUHAN KARYA ABDOEL MOEIS
}

\author{
Robiatul Aliyaha, Muhamad Yasser Irfan ${ }^{\mathrm{b}}$
}

Tadris Bahasa Indonesia, UIN Syarif Hidayatullah Jakarta

Jalan Ir. H. Juanda No. 95, Ciputat, 15412, Indonesia

pos-el: robiatulaaliyah@gmail.com ${ }^{\mathrm{a}}$, yasser.irfan15@mhs.uinjkt.ac.id ${ }^{\mathrm{b}}$

(Diterima: 9 Februari 2021; Direvisi: 27 Maret 2021; Disetujui: 30 April 2021)

\begin{abstract}
Abstrak
Perkembangan kesusastraan Indonesia pada periode awal ditandai dengan produksi bacaan kaum pergerakan yang sering disebut oleh bangsa kolonial sebagai bacaan liar. Penelitian ini bertujuan melihat pencitraan tokoh dalam upaya menyampaikan kritik terhadap bangsa kolonial dalam kedua novel. Teori yang digunakan yaitu kajian sastra bandingan dan sosiologi sastra sebagai alat analisis. Metode yang digunakan adalah analisis deskriptif. Hasil penelitian menunjukkan bahwa dalam novel Student Hidjo dan Salah Asuhan terdapat kritik yang ditunjukkan kepada bangsa kolonial, seperti kritik untuk memperoleh pendidikan yang sederajat dengan para elite bangsawan, kritik mengenai perbedaan kebudayaan antara bangsa Barat dan Timur, kritik mengenai perlakuan yang dilakukan oleh bangsa kolonial, dan kritik perilaku yang dimiliki bangsa kolonial. Penyampaian kritik pada novel Student Hidjo disampaikan dengan tersurat atau secara terang-terangan karena dengan mudah dipahami oleh para pembacanya. Sementara dalam novel Salah Asuhan, penyampaian kritik terhadap bangsa kolonial disampaikan secara tersirat. Hal tersebut dikarenakan novel itu diterbitkan pertama kali oleh Balai Pustaka sehingga menyiasati sensor-sensor yang berlaku dalam Balai Pustaka pada saat itu.

Kata kunci: bacaan liar, kritik kolonial, sastra bandingan, sosiologi sastra
\end{abstract}

\section{Feedback of The Colonial Through The Main Character's in Student Hidjo of Marco Kartodikromo, and Salah Asuhan of Abdoel Moeis}

\begin{abstract}
The production of early Indonesian literature was characterized by the reading production of movement groups referred to by colonial as wild reading. The study aims to see imagery of character to insinuate criticism towards the colonial in both novels. The theory was that studies of literary comparisons as analysis tools. The method used is a descriptive analysis. The research has shown that Student Hidjo and Salah Asuhan criticized colonists, a criticism of the cultural differences between the west and the east, a criticism of the treatment by the colonists, and a criticism of colonial behavior. The delivery of criticism in the Student Hidjo novel is explicitly or outright because the readers can easily understand it. While in Salah Asuhan novel, the delivery of criticism of the colonial nation is conveyed impliedly. Balai Pustaka first published it to investigate the sensors that apply in the Balai Pustaka at the time.
\end{abstract}

Keywords: Wild literature, colonial criticism, comparisons, sociology of literature

\section{PENDAHULUAN}

Sejarah sastra Indonesia dalam kurun waktu tahun 1900--1933 dikenal sebagai angkatan Balai Pustaka. Angkatan Balai Pustaka merupakan sekelompok sastrawan, penyair, dan penulis prosa yang menerbitkan karya-karyanya melalui Balai Pustaka. Balai Pustaka adalah lembaga resmi yang dibangun oleh pemerintah kolonial Belanda pada tahun 1908 dengan nama Commissie voor de Volkslectuur atau Komisi Bacaan Rakyat. Lembaga ini dibangun sebagai bentuk konsekuensi politik etis yang mendirikan sekolah bagi kaum Bumiputra (Taum, 2014: 130).

Selama ini, Balai Pustaka dikenal perintis dalam kesusastraan Indonesia 
modern. Melalui lembaga tersebut, karyakarya sastra penulis pribumi dapat dibaca luas oleh masyarakat. Pandangan seperti ini agaknya mengabaikan pendirian dan perkembangan Balai Pustaka sebagai lembaga kolonial yang berhadapan dengan masyarakat Hindia Belanda pada saat itu. Kecenderungan lain dalam pembahasan mengenai Balai Pustaka adalah pengamatan yang hanya diarahkan pada hubungan lembaga tersebut dengan perkembangan kesusastraan. Pengamatan seperti ini dapat menimbulkan pemahaman yang sama sekali keliru, hal tersebut dikarenakan Balai Pustaka jelas memiliki jangkauan yang lebih luas karena pengaruhnya dalam dunia kesastraan sangat besar.

Sementara itu, di luar angkatan resmi yang didirikan dan dibina oleh pemerintah kolonial, terdapat sekelompok sastrawan yang sangat aktif dalam menulis karyakarya sastra. Mereka tidak memublikasikan karya-karyanya melalui penerbit Balai Pustaka. Tahun 1924, organisasi PKI mendirikan Comissie Batjaan Hoofdbestuur yang menerbitkan dan menyebarluaskan "literatuur socialisme" sebuah istilah yang pertama kali digunakan oleh Semaoen. Dalam artikelnya, "Klub Kominis!", Semaoen menjelaskan bahwa "socialisme jalah ilmoe mengatoer pergaoelan idoep, soepaja dalem pergaoelan idoep itoe orang-orangnja djangan ada jang memeres satoe sama lain".

Perkembangan kesusastraan Indonesia pada periode awal ditandai dengan produksi bacaan kaum pergerakan yang sering disebut oleh bangsa kolonial sebagai bacaan liar (Erowati dan Bahtiar, 2011: 24). Jenis bacaan liar di antaranya terdiri atas sajak, cerpen, dan novel. Yang dianggap sebagai bacaan liar adalah bacaan yang memuat gagasan politik tertentu atau mengkritisi pemerintahan yang saat itu berkuasa sehingga hal tersebut dianggap dapat menimbulkan tindakan provokasi untuk melawan mereka.

Bacaan liar didasari penindasanpenindasan yang dilakukan oleh kaum kolonial sehingga masyarakat pada masa itu dapat melakukan tindakan provokasi untuk melawan dan menjelekkan kaum kolonial. Untuk mengurangi bacaan liar yang beredar di masyarakat serta makin tingginya minat baca, kaum kolonial (Belanda) mendirikan Kantor Bacaan Rakyat yang sekarang dikenal dengan Balai Pustaka. Latar belakang berdirinya Balai Pustaka berhubungan erat dengan kebijakan kaum kolonial saat itu.

Balai Pustaka didirikan oleh kolonial Belanda dalam upaya melakukan kontrol sosial dan politik terhadap bacaan-bacaan liar (teks bacaan yang diterbitkan oleh komunitas Tionghoa, Arab, dan pribumi) di Indonesia. Kontrol sosial dan politik dilakukan dalam upaya mengeksistensikan dirinya sebagai satu-satunya penjajah yang menaklukkan pribumi seutuhnya. Oleh karena itu, semua bacaan yang diterbitkan ada dalam pengawasan dan sensor kekuasaannya (Artawan and Yasa, 2015: 578). Novel Salah Asuhan, Siti Nurbaya, dan Belenggu adalah karya-karya sastra yang sudah mengalami sensor dari tangan kolonial sebelum akhirnya teks-teks (novel-novel) itu dibaca masyarakat luas. Novel-novel itu harus sesuai dengan standar bacaan yang sudah ditetapkan oleh Balai Pustaka berdasarkan keputusan D. A. Rinkes, Direktur Balai Pustaka. Salah satunya adalah karya sastra yang diterbitkan tidak bertentangan dengan garis politik pemerintah kolonial Belanda. 
Pemerintah kolonial menciptakan sensorsensor yang berlaku sebagai upaya menciptakan sebuah pencitraan diri, orientalisme, dan tetap menempatkan pribumi sebagai budak, budak pekerja dan budak peniru budaya-budaya Barat. Meskipun demikian, novel-novel Balai Pustaka menunjukkan perlawanan secara tersembunyi dari para pengarang (Yasa, 2014: 250).

Pada dasarnya, bacaan-bacaan yang dihasilkan oleh para pemimpin pergerakan pada awal abad ke-20 dapat dikategorikan sebagai bacaan politik. Hampir semua bacaan yang diproduksi oleh para pemimpin pergerakan baik berbentuk novel, puisi, roman, surat perlawanan persdelict, dan cerita bersambung, isinya menampilkan kekritisan dan perlawanan terhadap tata kuasa kolonial. Sejarah mencatat, sesungguhnya sastra Indonesia sejak mula sejarahnya merupakan sastra protes (Sulton, 2015: 214).

Pada saat berdirinya, Balai Pustaka menimbulkan dampak dalam perkembangan sejarah Indonesia sebelum kemerdekaan, baik dampak positif maupun dampak negatif. Dampak positif didirikannya Balai Pustaka adalah perkembangan dan kemajuan sastra menjadi pesat, sertamembangkitkan semangat pengarang-pengarang muda untuk mengembangkan bakat mereka. Sedangkan dampak negatifnya adalah pengarang tidak bebas dalam mengemukakan pikiran serta perasaannya karena harus menyesuaikan dengan ketentuan yang telah ditetapkan oleh Balai Pustaka. Ketentuan Balai Pustaka dibuat oleh bangsa kolonial saat itu sehingga karya sastra yang tidak diterbitkan atau tidak memenuhi kriteria yang telah ditetapkan oleh Balai Pustaka dinamakan dengan bacaan liar.

Beberapa penelitian mengangkat novel Student Hidjo dan Salah Asuhan sebagai objek materialnya. Pertama, skripsi dengan judul "Kawin Paksa dalam Novel Indonesia Salah Asuhan dan Novel Malaysia Mencari Istri: Sebuah Studi Perbandingan" karya Sri H. Wijayanti pada tahun 1989. Skripsi tersebut membahas perbandingan kawin paksa dalam novel Salah Asuhan dengan Malaysia Mencari Istri. Persamaan penelitian ini dengan penelitian yang dilakukan oleh Sri H. Wijayanti terletak pada novel yang dijadikan sebagai objek penelitian, yaitu novel Salah Asuhan. Perbedaan penelitian Sri H. Wijayanti dengan penelitian ini terletak pada analisis yang dilakukan. Jika Sri H. Wijayanti membahas mengenai kawin paksa yang terdapat pada novel Salah Asuhan dan Malaysia Mencari Isti serta melihat sikap kedua pengarang novel tersebut terhadap masalah kawin paksa yang terdapat pada kedua novel tersebut, penelitian ini membahas kritik terhadap bangsa kolonial yang digambarkan melalui tokoh utama dalam novel Student Hidjo dan Salah Asuhan.

Kedua, tesis yang berjudul "Ide Antikolonialisme Tokoh-tokoh Perempuan dalam Tiga Karya Marco Kartodikromo: Suatu Tinjauan Pascakolonial" karya Novi Diah Haryanti pada tahun 2011. Tesis tersebut membahas ide antikolonialisme yang direpresentasikan oleh tokoh-tokoh perempuan dalam novel Student Hidjo, 
Matahariah, dan Rasa Mardika. Persamaan penelitian yang dilakukan oleh Novi Diah Haryanti dengan penelitian ini adalah mencari ide antikolonialisme berupa kritik untuk bangsa kolonial yang terdapat pada novel Student Hidjo. Sementara perbedaannya terletak pada tujuan dan objek penelitian. Penelitian yang dilakukan oleh Novi Diah Haryanti mencari ide antikolonialisme pada tokohtokoh perempuan dalam tiga novel karya Marco Kartodikromo, sementara penelitian ini mencari kritik terhadap bangsa kolonial melalui penggambaran tokoh utama pada novel Student Hidjo dan Salah Asuhan. Selain itu, penelitian ini hanya membandingkan dua novel yaitu novel Student Hidjo dan Salah Asuhan, sedangkan Novi Diah Haryanti dalam penelitiannya menggunakan tiga novel yaitu Student Hidjo, Matahariah, dan Rasa Mardika.

Ketiga, jurnal Kawistara Vol. 3 No. 2 (2013), hlm. 178--185 dengan judul "Konstruksi Nasionalisme dalam Novelnovel Indonesia Prakemerdekaan (Student Hijo dan Salah Asuhan)" karya Wiyatmi. Artikel di jurnal tersebut membahas konstruksi nasionalisme yang terdapat dalam novel-novel Indonesia prakemerdekaan, khususnya dalam novel Student Hidjo karya Marco Kartodikromo dan Salah Asuhan karya Abdoel Moeis. Persamaan antara penelitian ini dengan penelitian yang dilakukan oleh Wiyatmi adalah novel yang dijadikan sumber primer penelitian, yaitu novel Student Hidjo dan Salah Asuhan. Sementara perbedaannya terletak pada tujuan penulisan, penelitian ini bertujuan mencari kritik-kritik yang ditujukan pada bangsa kolonial di dalam kedua novel tersebut. Sementara penelitian yang dilakukan oleh Wiyatmi membahas konstruksi ideologi nasionalisme oleh kedua pengarang novel tersebut.

Keempat, jurnal Pena Literasi Vol. 1, No. 1 (2018), h. 32-44 dengan judul "Perbandingan Karakter Tokoh Utama Novel Salah Asuhan Karya Abdoel Moeis dan Belenggu Karya Armijn Pane" karya Poni Ernis. Artikel di jurnal tersebut membahas perbandingan tokoh utama dalam novel Salah Asuhan karya Abdoel Moeis dengan Belenggu karya Armijn Pane. Selain itu, dalam penelitian Porni Ernis juga dijelaskan letak persamaan dan perbedaan keduanya. Persamaan penelitian ini dengan penelitian yang dilakukan oleh Poni Ernis adalah mengenai perbandingan tokoh pada dua novel yang berbeda. Sementara itu, letak perbedaannya adalah pada tujuan penulisan. Jika Poni Ernis dalam penelitiannya bertujuan membandingkan tokoh utama dan mencari persamaan serta perbedaan yang terdapat dalam novel Salah Asuhan dan Belenggu, penelitian ini bertujuan mencari kritikkritik yang berusaha digambarkan pengarang melalui tokoh utama pada novel Student Hidjo karya Marco Kartodikromo dan Salah Asuhan karya Abdoel Moeis.

Berdasarkan judul penelitian ini, masalah yang dirumuskan adalah perbandingan citra tokoh utama dalam novel Student Hidjo karya Marco Kartodikromo dengan Salah Asuhan karya Abdoel Moeis. Selain itu, penelitian ini juga membahas apa saja kritik yang ditunjukan kepada bangsa kolonial melalui penggambaran tokoh utama pada kedua novel tersebut. Hasil penelitian ini diharapkan dapat mengedukasi generasi penerus bangsa mengenai wawasan terhadap sastra Indonesia yang berkaitan dengan sastrawan dan karyanya yang 
dianggap dan diberikan cap oleh masyarakat tertentu.

\section{TEORI}

Novel merupakan produk budaya yang hadir sebagai respon realitas dan merekam jejak historis suatu peradaban. Novel diciptakan pengarang dengan maksud tertentu. Oleh karena itu, sisi historis novel termasuk yang merekam kisah-kisah kolonialisme. Biasanya, novel yang merekam kondisi kolonial tersebut, hadir sebagai ciptaan kaum terjajah maupun dari pihak penjajah (Mahattir, 2020: 217).

Pada penelitian ini, data primer penelitian adalah dua novelyang dibandingkan isinya. Dalam melakukan proses perbandingan, diperlukan ilmu sastra yang disebut sastra bandingan.

Menurut Remak (1990) dalam (Damono, 2015: 1), sastra bandingan adalah kajian sastra di luar batas-batas sebuah negara dan kajian hubungan di antara sastra dengan bidang ilmu serta kepercayaan seperti seni, filsafat, sejarah, sains sosial, sains, agama, dll.

Sastra bandingan tidak sekadar mempertentangkan dua sastra dari dua negara atau bangsa yang mempunyai bahasa yang berbeda, tetapi sastra bandingan merupakan metode memperluas pendekatan atas sastra suatu bangsa saja. Sastra bandingan bukan hanya sekadar mempertentangkan dua sastra dari dua negara atau bangsa. Perbandingan tidak hanya terbatas pada sastra antarbangsa, tetapi juga sesama bangsa sendiri, misalnya antarpengarang, antargenetik, antarzaman, antarbentuk, dan antartema. (Damono, 2015: 6-8). Kajian sastra bandingan tidak dapat mengabaikan peranan sastra nasional dan sastra dunia. Adanya sastra dunia merupakan prasyarat untuk kajian sastra bandingan (Kasim, 1996: 11).

Penelitian ini dilakukan dengan menggunakan pendekatan sosiologi sastra. Penelitian sosiologi sastra adalah pemahaman terhadap karya sastra sekaligus hubungannya dengan masyarakat yang melatarbelakanginya (Ratna, 2013: 2). Sosiologis dan sastra berurusan dengan hal yang sama yaitu manusia dalam masyarakat. Sosiologi adalah suatu telaah objektif dan ilmiah tentang manusia dalam masyarakat, tentang sosial, dan proses sosial. Sementara itu, sastra adalah lembaga sosial yang menggunakan bahasa sebagai mediumnya, bahasa itu merupakan ciptaan sosial yang menampilkan gambaran kehidupan (Semi, 1993: 52).

Kritik sosial dalam karya sastra (dewasa ini) tidak lagi hanya menyangkut hubungan antara orang miskin dan orang kaya, kemiskinan dan kemewahan. Kritik sosial mencakup segala macam masalah sosial yang ada di masyarakat, hubungan manusia dengan lingkungan, kelompok sosial, penguasa dan institusi-institusi yang ada (Damono, 1979: 25). Kritik sosial diangkat ketika kehidupan dinilai tidak selaras dan tidak harmonis, ketika masalah-masalah sosial tidak dapat diatasi dan perubahan sosial mengarah kepada dampak-dampak disosiatif dalam masyarakat (Praptiwi, 2014: 2)

\section{METODE}

Jenis penelitian yang dilakukan pada penelitian ini adalah kualitatif, yaitu 
penelitian yang bermaksud memahami fenomena tentang apa yang dialami oleh subjek penelitian, misalnya perilaku, persepsi, motivasi, tindakan, dan lain-lain secara holistik dengan data deskripsi dalam bentuk kata-kata dan bahasa, pada konteks khusus yang alamiah dengan memanfaatkan beberapa metode ilmiah (Moleong, 2005: 6). Sementara data primer pada penelitian ini adalah novel Student Hidjo karya Marco Kartodikromo dan Salah Asuhan karya Abdoel Moeis. Data yang akan diteliti dalam penelitian ini berupa kata-kata, kalimat, atau paragraf yang membahas mengenai penggambaran tokoh utama oleh pengarang sebagai upaya kritik terhadap bangsa kolonial, baik itu secara tersurat maupun tersirat yang terdapat dalam kedua novel tersebut.

Metode deskriptif yang digunakan memberikan analisis data yang digunakan adalah deskriptif. Metode analisis deskriptif adalah statistik yang digunakan untuk menganalisis data dengan cara mendeskripsikan atau menggambarkan data yang telah terkumpul tanpa adanya maksud membuat kesimpulan yang berlaku untuk umum atau generalisasi (Sugiono, 2011: 147). Teknik yang dilakukan adalah mengumpulkan data dengan cara mencatat data-data, menganalisis, menafsirkan data, mengkaji dengan membandingkan teks tersebut, dan menyimpulkan hubungan data teks dengan teori yang digunakan. Berdasarkan hal tersebut, sasaran penelitian ini adalah unsur-unsur kritik terhadap bangsa kolonial yang terkandung dalam kedua novel tersebut.

\section{HASIL DAN PEMBAHASAN}

Novel Student Hidjo karya Marco Kartodikromo adalah salah satu bacaan liar. Novel tersebut menceritakan budaya 80 serta lahirnya intelektualitas dari kalangan borjuis. Di dalam novel Student Hidjo juga menggambarkan situasi pada saat itu, seperti ketidakadilan yang diperoleh oleh bangsa Hindia Belanda. Tidak heran dalam novelnya tersebut banyak alur cerita yang mengkritik tentang sifat dan budaya bangsa kolonial. Sementara itu, novel Salah Asuhan karya Abdoel Moeis tidak termasuk ke dalam bacaan liar. Hal ini dikarenakan novel tersebut diterbitkan oleh Balai Pustaka. Namun, meski diterbitkan oleh Balai Pustaka, setidaknya ada beberapa kritik yang ditunjukkan untuk bangsa kolonial pada saat itu. Kritik yang terdapat dalam novel Salah Asuhan dituliskan secara tersirat oleh pengarang.

Tokoh yang terdapat pada novel Student Hidjo karya Marco Kartodikromo dan Salah Asuhan karya Abdoel Moeis memiliki kesamaan. Hal ini dikarenakan peneliti hanya melihat tokoh utama pada kedua novel tersebut. Tokoh utama pada novel Student Hidjo dan Salah Asuhan adalah laki-laki, yaitu Hidjo dan Hanafi. Sementara itu, tokoh pendukung yang sekiranya memiliki pengaruh terhadap alur cerita memiliki perbedaan. Pada novel Student Hidjo terdapat lima tokoh yang memiliki pengaruh terhadap alur cerita maupun tokoh utama. Tokoh tersebut adalah Raden Ajeng Biroe, Raden Ajeng Woengoe, Raden Potronojo, Raden Nganten Potronojo, dan Betje. Sedangkan di dalam novel Salah Asuhan terdapat tiga tokoh, yaitu Corrie, Rapiah, dan Mariam.

Penokohan adalah cara pengarang dalam menggambarkan dan mengembangkan karakter tokoh-tokoh dalam cerita (Kosasih, 2008: 61). Penelitian ini hanya fokus mendeskripsikan tokoh utama pada novel Student Hidjo dan Salah Asuhan. Tokoh 
tersebut adalah Hidjo dan Hanafi. Kedua tokoh memiliki karakter yang sangat kontras. Tokoh Hidjo dalam novel Student Hidjo digambarkan memiliki kepribadian yang pintar, santun, dan menghormati kedua orang tuanya. Sementara tokoh Hanafi dalam novel Salah Asuhan digambarkan sebagai pemuda yang tidak menghargai adat istiadat, pemarah, dan tidak menghormati ibunya.

Alur yang terdapat pada novel Student Hidjo karya Marco Kartodikromo dan Salah Asuhan karya Abdoel Moeis adalah alur maju. Hal ini dapat dilihat pada bagian awal cerita yang ditandai dengan pengenalan tokoh atau pun latar yang terdapat dalam kedua novel tersebut. Setelah itu pada bagian akhir cerita kedua novel tersebut menceritakan penyelesaian konflik yang selama ini dialami oleh tokoh utama pada masing-masing novel, Student Hidjo dan Salah Asuhan.

Latar tempat yang terdapat pada novel Student Hidjo adalah Jawa dan Belanda, sedangkan di dalam novel Salah Asuhan adalah Sumatra Barat dan Betawi. Sementara itu, Latar waktu yang terdapat pada novel Student Hidjo adalah sekitar tahun 1906-an. Hal ini dilihat dari beberapa fakta teks yang terdapat dalam novel Student Hidjo yang menyatakan diadakannya kongres Sarekat Islam pertama kali di Solo, sedangkan pada novel Salah Asuhan diceritakan dengan latar waktu sekitar tahun 1920-an. Hal ini dapat dilihat pada teks yang terdapat dalam novel mengenai politik etis. Politik ini lahir pada tahun 1901. Artinya, latar waktu dalam novel Salah Asuhan ialah setelah berlakunya kebijakan dalam politik etis.
Latar yang terakhir adalah latar suasana. Latar suasana yang digambarkan pada novel Student Hidjo adalah banyaknya ungkapan perasaan hati dari setiap tokohnya, seperti marah, sedih, kecewa, senang, dan lainnya. Sedangkan latar suasana di dalam novel Salah Asuhan digambarkan dengan perilaku atau watak yang dimiliki pada setiap tokoh dalam menjalani kehidupannya.

\section{Penyampaian kritik melalui pencitraan tokoh utama}

Novel Student Hidjo karya Marco Kartodikromo adalah novel yang terbit sebelum kemerdekaan atau sekitar tahun 1919. Novel ini menceritakan tentang pertentangan antara kaum pribumi kelas menengah ke atas (borjuis) dengan kaum kolonial. Selain itu, novel Student Hidjo juga menggambarkan awal mula lahirnya intelektual dari kalangan borjuis yang secara berani menggambarkan kehidupan di Belanda dan Hindia Belanda saat itu. Novel Student Hidjo terbit sesudah didirikannya Balai Pustaka. Sementara novel Salah Asuhan karya Abdoel Moeis adalah novel yang juga diterbitkan sebelum kemerdekaan, yakni sekitar tahun 1928. Novel ini mengisahkan percintaan seorang pemuda pribumi yang mencintai wanita cantik keturunan Eropa. Adanya perbedaan bangsa dan budaya di antara keduanya telah menimbulkan sebuah permasalahan dalam ikatan persahabatan dan percintaan mereka. Selain itu, novel ini juga menggambarkan keadaan sosial atau kehidupan pada saat itu, seperti kedudukan bangsa kolonial terhadap bangsa pribumi. 
Balai Pustaka didirikan pada 22 September 1977 (Muhri, 2014: 30). Salah satu dampak negatif didirikannya Balai Pustaka adalah pengarang tidak bebas dalam mengemukakan pikiran dan perasaan karena harus menyesuaikan dengan ketentuan-ketentuan pemerintah Hindia Belanda. Oleh karena itu, karyakarya yang tidak memenuhi kriteria yang ditetapkan atau diterbitkan di luar Balai Pustaka dikenal dengan "Bacaan Liar", di antaranya novel Student Hidjo. Novel ini dipandang sebagai perintis tradisi sastra Indonesia karena telah menyuarakan semangat kebangsaan dan perlawanan terhadap kolonialisme (K.S, 2007: 110). Marco Kartodikromo adalah orang yang paling produktif dalam menghasilkan "Bacaan Liar"(WS, 2009: 588). Tidak heran jika di dalam novel Student Hidjo terdapat beberapa kritikan yang ditunjukkan untuk kaum kolonial.

Berbeda dengan novel Student Hidjo, novel Salah Asuhan merupakan novel yang diterbitkan oleh Balai Pustaka. Novel yang ditulis oleh Abdoel Moeis ini tentu sudah mengalami sensor dari tangan bangsa kolonial pada saat itu melalui peraturan yang ada di Balai Pustaka. Namun, tidak menutup kemungkinan seorang Abdoel Moeis menyampaikan kritik terhadap bangsa kolonial atau antikolonialisme. Seperti yang sudah diketahui, Abdoel Moeis merupakan pahlawan nasional Indonesia yang berjuang melawan bangsa kolonial, salah satunya adalah melalui hasil karya-karya tulis yang pernah dia buat. Oleh karena itu, peneliti mencoba mencari kritik terhadap bangsa kolonial yang diungkapkan secara tersirat maupun tersurat oleh Abdoel Moeis dalam novel Salah Asuhan.
Sebelum menganalisis isi untuk menemukan kritik-kritik yang terdapat di dalam novel Student Hidjo dan Salah Asuhan, ada baiknya untuk mengetahui secara umum karakteristik atau watak yang dimiliki tokoh utama pada kedua novel tersebut. Pada penelitian ini, peneliti menganggap bahwa tokoh utama pada novel Student Hidjo adalah Hidjo dan Salah Asuhan adalah Hanafi. Hal ini dikarenakan, kedua tokoh tersebut memiliki peranan yang sangat penting dalam rangkaian cerita pada kedua novel yang diterbitkan sebelum kemerdekaan itu.

Tokoh Hidjo dalam novel Student Hidjo digambarkan sebagai tokoh yang memiliki kecerdasaan dalam pemikirannya. Hidjo merupakan seorang pemuda yang berhasil menamatkan sekolahnya di Hoogere Burgerschool (HBS). Seperti yang sudah diketahui, HBS adalah sekolah pendidikan menengah umum yang didirikan oleh Belanda. Bahasa pengantar yang digunakan pada sekolah tersebut adalah bahasa Belanda. Tidak semua kalangan dapat bersekolah di HBS, hanya orang Eropa, Belanda, dan elite pribumi sajalah yang dapat mengenyam pendidikan di sana. Selain itu, Hidjo juga digambarkan sebagai tokoh yang memiliki pemikiran yang maju dan kritis. Hal tersebut diungkapkan tokoh Raden Potronojo, ayah Hidjo pada kutipan berikut.

"Pikirkanlah, zaman sekarang ini, anak-anak lelaki harus mempunyai kepandaian yang sepantasnya. Sebab kalau tidak begitu, anakmu akan kesulitan mendapatkan pekerjaan. Benar, Hidjo sudah tamat belajarnya di HBS, tetapi karena rupanya dia sangat maju dalam belajarnya dan pikirannya tajam, maka sebaiknya dia saya suruh meneruskan belajarnya agar menjadi 
ingenieur di Negeri Belanda. ..."(Kartodikromo, 2010: 5).

Sementara itu, tokoh Hanafi dalam novel Salah Asuhan setidaknya digambarkan memiliki persamaan dengan tokoh Hidjo pada novel Student Hidjo. Meski secara umum, tokoh Hanafi di dalam novel diceritakan sebagai tokoh yang memiliki watak yang negatif, seperti keras kepala, sombong, dan lain sebagainya. Namun, tokoh Hanafi memiliki kecerdasan dalam pemikirannya. Karakteristik tersebutlah yang menjadi sisi kemiripan antara tokoh Hanafi dengan Hidjo. Tokoh Hanafi di dalam novel diceritakan bahwa dia bersekolah di HBS selama tiga tahun. Dia disekolahkan oleh ibunya dengan tujuan menjadikannya anak yang pandai. Berikut kutipan yang menyatakan hal tersebut.

"Tamat sekolah rendah, berpindahlah ia ke HBS, yang dijalaninya sampai tiga tahun. Sebab ibunya berasa sudah tua, dan lama pula merindukan anaknya, maka sekolah Hanafi diputuskan saja di situ, ..." (Moeis, 2010: 27).

Kecerdasaan yang dimiliki oleh tokoh Hidjo dan Hanafi menjadikan keduanya memiliki sisi persamaan dari segi watak. Sementara itu, terdapat perbedaan yang sangat kontras antara kedua tokoh tersebut.

Tokoh Hidjo dalam karya Marco Kartodikromo secara umum digambarkan sebagai pemudadengan watak yang positif, seperti sopan, santun, rajin, pendiam, dan menghormati kedua orang tuanya. Watak tokoh Hidjo tersebut diungkapkan oleh tokoh Raden Ajeng Woengoe pada kutipan berikut.
"Ayah, Ibu, dan saudara lelaki saya cinta sekali sama Tuan Hidjo. Sebab dia pintar dan halus budi bahasanya. Kalau dia tak ditanya, dia tidak berkata. Dia pendiam sekali." (Kartodikromo, 2010: 35)

Berbeda dengan tokoh Hidjo, tokoh Hanafi dalam novel Salah Asuhan karya Abdoel Moeis memiliki kepribadian yang negatif. Karakteristik yang dimiliki tokoh Hanafi adalah sombong, angkuh, dan suka merendahkan orang lain. Penyebab timbulnya watak-watak yang melekat pada dirinya tak lain karena pendidikan bangsa Barat yang didapatinya sejak kecil. Oleh karena itu, Hanafi merasa derajat dirinya lebih tinggi daripada bangsanya sendiri. Tak hanya itu, Hanafi juga menganggap bahwa bangsanya adalah bangsa yang rendah dan bodoh. Menurut dia, bangsanya tidak bisa mengikuti kemajuan zaman. Hal tersebut dapat dilihat pada perkataan Hanafi kepada ibunya berikut ini.

"Itulah salahnya, Ibu, bangsa kita dari kampung; tidak suka menurutkan putaran zaman. Lebih suka duduk rungkuh dan duduk mengukul saja sepanjang hari. Tidak ubah dengan kerbau bangsa kita, Bu! Dan segala sirih menyirih itu ... brrrr!"(Moeis, 2010: 28-29).

Setelah mengetahui secara umum watak yang dimiliki oleh tokoh Hidjo dalam Student Hidjo dan Hanafi dalam Salah Asuhan, pembahasan berikutnya terkait kritik-kritik terhadap bangsa kolonial yang digambarkan oleh pengarang melalui kedua tokoh tersebut. Kritik yang terdapat pada kedua novel adalah hak untuk memperoleh pendidikan yang sama atau sederajat dengan para bangsawan saat itu. Pada bagian awal novel Student Hidjo 
dapat ditemui kritik mengenai hal tersebut. Kritik untuk memperoleh pendidikan yang sederajat dengan para bangsawan saat itu, diungkapkan Marco Kartodikromo dengan penceritaan tokoh Hidjo yang akan disekolahkan ke Belanda oleh Raden Potronojo, ayah dari tokoh Hidjo. Alasan Hidjo disekolahkan ke Belanda adalah karena Hidjo memiliki kecerdasaan dalam menempuh pendidikannya. Selain itu, tokoh Hidjo juga digambarkan sebagai tokoh yang memiliki pemikiran yang tajam atau kritis. Alasan lain yang mendasari tokoh Hidjo akan disekolahkan ke Belanda adalah karena ayahnya menginginkan Hidjo menjadi seorang insinyur. Ayahnya beranggapan bahwa dengan menyekolahkan anaknya di Belanda dan menjadi seorang insinyur, maka derajat keluarga mereka akan terangkat. Raden Potronojo sangat mengharapkan Hidjo dapat bekerja di dalam pemerintahan. Meskipun ayah Hidjo, Raden Potronojo merupakan seorang saudagar yang berhasil, tak lantas mendapatkan kesetaraan sosial di dalam lingkungan tempat tinggalnya, khususnya di mata orang-orang yang bekerja di dalam pemerintahan. Seperti yang sudah diketahui, pada saat itu orang-orang yang bekerja di dalam pemerintahan memiliki strata sosial atau derajat yang lebih tinggi di dalam masyarakat. Seperti pada kutipan berikut.

“... Benar, Hidjo sudah tamat belajarnya dari HBS, tetapi karena rupanya dia sangat maju dalam belajarnya dan pikirannya tajam, maka sebaiknya dia saya suruh meneruskan belajarnya agar menjadi ingenieur di Negeri Belanda. ..." (Kartodikromo, 2010: 5)

"Saya ini hanya seorang saudagar. Kamu tahu sendiri. Waktu ini, orang seperti saya masih dipandang rendah oleh orang-orang yang menjadi pegawai Gouvernement. Kadangkadang saudara kita sendiri, yang juga turut menjadi pegawai Gouvernement, dia tidak mau kumpul dengan kita. Sebab dia pikir derajatnya lebih tinggi daripada kita yang hanya menjadi saudagar dan petani. Maksud saya mengirimkan Hidjo ke Negeri Belanda itu, tak lain supaya orang-orang yang merendahkan kita bisa mengerti bahwa manusia itu sama saja. Buktinya anak kita juga bisa belajar seperti regentregent dan pangeran-pangeran." (Kartodikromo, 2010: 6).

Sementara itu dalam novel Salah Asuhan, Abdoel Moeis juga menyampaikan kritikan yang serupa mengenai hak untuk memperoleh pendidikan yang sederajat dengan para elite bangsawan pada saat itu. Pada novel Salah Asuhan kritikan tersebut digambarkan melalui tokoh Hanafi. Seperti yang sudah diketahui, bahwa Hanafi sejak kecil sudah disekolahkan di HBS, Betawi. HBS adalah sekolah pendidikan menengah umum yang didirikan oleh Belanda. Tidak semua kalangan dapat bersekolah di HBS, hanya orang Eropa, Belanda, dan elite pribumi sajalah yang dapat mengenyam pendidikan di sana. Sejak mengenyam pendidikan di HBS itulah tak heran, jika di dalam novel tokoh Hanafi tidak hanya digambarkan sebagai tokoh yang berpendidikan tinggi, namun juga memiliki pandangan dan kepribadian yang kebaratbaratan. Selama bersekolah di HBS, Hanafi dibiayai oleh ibu dan pamannya. Ibu Hanafi hanyalah seorang perempuan kampung, namun dia mampu untuk menyekolahkan anaknya di HBS. Mariam, ibu Hanafi memiliki tujuan ketika menyekolahkan putranya tersebut. Tujuan 
dia adalah menjadikan Hanafi anak yang pandai, melebihi keluarganya di kampung. Hal tersebut dapat dilihat pada kutipan berikut.

"Dari kecil Hanafi sudah disekolahkan

di Betawi, yaitu tidak dinantikan tamatnya bersekolah Belanda di Solok, tetapi dipindahkan ke ibu kota itu karena kata ibunya, ia tidak hendak kepalang menyekolahkan anak tunggal yang sudah kehilangan ayah itu. Sebab ibunya ada di dalam berkecukupan, dapatlah ia menumpangkan Hanafi di rumah orang Belanda yang patut-patut. Maksud orang tua itu ialah supaya anaknya menjadi orang pandai, melebihi kaum keluarganya dari kampung."(Moeis, 2010: 27).

Tidak hanya mengkritik mengenai hak memperoleh pendidikan. Pada kedua novel tersebut juga ditemukan adanya kritik mengenai kebudayaan Barat dan Timur. Kritik tersebut ditujukan pada bangsa kolonial yang memiliki kebudayaan Barat dan kaum pribumi yang menganut kebudayaan Timur. Pada novel Student Hidjo, kebudayaan Barat digambarkan sebagai budaya dengan pergaulan bebas dan banyaknya wanita "penggoda", sedangkan kaum pribumi yang menganut kebudayaan Timur digambarkan memiliki sifat-sifat yang positif dalam kesehariannya, seperti sopan dan menghargai sesama. Kritikan tersebut digambarkan melalui tindakan tokoh Hidjo ketika dia sedang berjalan dengan dua wanita Belanda, yaitu Betje dan Marie. Tokoh Hidjo berusaha menghargai kebudayaan Barat saat berjalan dengan dua wanita tersebut. Seperti pada kutipan berikut ini.

\begin{abstract}
"Sekarang Hidjo berada di kalangan dua gadis bangsa Eropa, sudah barang tentu Hidjo harus memakai adat Eropa yang telah beberapa tahun ia jalankan di HBS di Tanah Jawa. Meskipun adat Eropa di Negeri Belanda lebih bebas (vrij) daripada adat Eropa di Tanah Hindia. Tetapi Hidjo tidak kebingungan tambah kebebasannya."(Kartodikromo, 2010: 45)
\end{abstract}

Berbeda dengan tokoh Hidjo yang merepresentasikan kebudayaan Timur dengan memiliki kepribadian yang sopan dan menghargai sesama manusia, tokoh Hanafi merupakan representasi dari kebudayaan Barat. Meski tokoh Hanafi sendiri berasal dari kaum pribumi, namun hal tersebut tidak membuatnya menganut kebudayaan Timur. Hal tersebut dikarenakan adanya pengaruh saat dia bersekolah di HBS sehingga pemikiran dan gaya hidupnya menjadi kebarat-baratan. Tokoh Hanafi digambarkan memiliki watak yang keras dan suka merendahkan bangsanya sendiri. Hal tersebut diungkapkan oleh Hanafi ketika berkata kepada ibunya mengenai persoalan kesukaan atau kebiasaan ibunya, seperti duduk bersimpuh. Hanafi yang merasa risih dengan kebiasaan ibunya tersebut, lantas menghina ibu dan bangsanya sendiri. Berdasarkan penjabaran tokoh Hanafi di atas, kutipan yang menyatakan hal tersebut adalah sebagai berikut.

"Tapi sepanjang hari orang tua itu termangu-mangu saja, karena dari beranda muka sampai ke dapur dan kamar mandi diperbuat secara aturan rumah orang Belanda. ..."(Moeis, 2010: 28). 
"Itulah salahnya, Ibu, bangsa kita dari kampung; tidak suka menurutkan putaran zaman. Lebih suka duduk rungkuh dan duduk mengukul saja sepanjang hari. Tidak ubah dengan kerbau bangsa kita, Bu! Dan segala sirih menyirih itu ... brrrr!"'(Moeis, 2010: 28-29).

Kritik lain yang terdapat dalam novel Student Hidjo adalah ketika Hidjo dan leerar-nya sampai di Amsterdam, Belanda. Saat mereka sampai di negeri Belanda, negeri tersebut sedang mengalami musim panas, di mana pada musim itu siang dan malam banyak orang-orang yang berpergian. Sewaktu Hidjo turun dari kapal, Hidjo melihat di pelabuhan sudah banyak orang-orang yang hendak menjemput saudara-saudara mereka. Pada saat itu, Hidjo merasa sangat hebat dan luar biasa. Hal tersebut dikarenakan Hidjo dapat memerintah orang Belanda dengan sesuka hatinya untuk membawakan perlengkapannya.

Sebagaimana diketahui, orang-orang Belanda yang berada di Hindia Belanda pada saat itu memiliki sifat yang angkuh dan besar kepala. Setelah itu, ketika Hidjo dan leerar-nya sampai di hotel, mereka benar-benar dihormati oleh para pelayan hotel. Kritik yang hendak disampaikan Marco Kartodikromo kepada bangsa kolonial adalah bahwa bangsa kolonial dapat diperlakukan hal yang serupa, seperti apa yang mereka lakukan kepada kaum pribumi di Hindia Belanda pada saat itu. Bangsa kolonial di Hindia Belanda pada saat itu memperlakukan kaum pribumi dengan hina dan sesuka hati mereka. Seperti pada kutipan berikut.

“... Tetapi luar biasa karena mulai saat itu Hidjo bisa memerintah orang-orang Belanda. Orang yang mana kalau di Tanah Hindia kebanyakan bersifat besar kapala." (Kartodikromo, 2010: 41).

"Setelah Hidjo dan leerar-nya turun dari kapal, mereka langsung ke hotel. Kedatangannya di situ, Hidjo dihormati betul oleh para pelayan hotel. Sebab mereka pikir, kalau orang baru datang dari Tanah Hindia pasti banyak uangnya. Leih-lebih kalau orang Jawa. Maka dari itu Hidjo tertawa dalam hati melihat keadaan serupa itu. Karena ia ingat nasib bangsanya sama dihina oleh bangsa Belanda." (Kartodikromo, 2010: 41)

Sementara itu, kritik yang coba disampaikan oleh Abdoel Moeis dalam novel Salah Asuhan adalah mengenai rasa kekeluargaan atau kemanusiaan yang dimiliki oleh bangsa kolonial. Kaum pribumi yang menganut kebudayaan Timur selalu memiliki rasa kepedulian atau kekeluargaan dalam keseharian mereka. Mereka tak segan membantu seseorang dengan ikhlas. Namun, hal itu berbeda bagi bangsa kolonial. Bangsa kolonial terkadang setengah hati menolong seseorang. Hal itulah yang terdapat di pikiran tokoh Hanafi melalui kejadian yang dia alami. Dalam novel Salah Asuhan dikisahkan Hanafi mendapatkan tumpangan rumah keluarga Belanda. Hanya saja terkadang ia merasa tidak diterima di dalam rumah itu. Hal tersebut dapat dilihat pada kutipan berikut.

"Dengan susah payah, Hanafi mendapat tumpangan di rumah suatu famili bangsa Belanda, kawan sekerja. Tuan rumah, yang bersahabat dengan Hanafi di tempat pekerjaan, sudah menerima kawan itu di rumahnya dengan setulus-tulus hatinya; akan tetapi nyonya, yang memandang Hanafi sebagai orang yang sudah 'tersesat', hanya terpandang kepada 
uang tumpangan yang $\mathrm{Rp} \quad 1000,00$ sebulan saja."(Moeis, 2010: 247)

Meskipun budi nyonya itu tidak kasar, tetapi di dalam sesuatu hal terasa oleh Hanafi, bahwa ia di dalam rumah itu diterima orang dengan setengah hati saja, seolah-olah mengawani orang tidak takut. ..."(Moeis, 2010: 247)

Pada novel Student Hidjo juga diceritakan mengenai kehidupan tokoh Hidjo selama tinggal di negeri Belanda. Hidjo diceritakan sering memperlakukan orang-orang Belanda sesuai dengan keinginannya. Sama halnya dengan perlakuan orang-orang Belanda (bangsa kolonial) di Hindia Belanda pada saat itu. Banyak bagian-bagian dalam cerita, bagaimana tokoh Hidjo memerintah orangorang Belanda dengan sesuka hatinya. Seperti saat Hidjo berada di buffet, Hidjo dengan lantangnya memanggil pelayan yang ada di buffet dan pelayan tersebut cepat menghampiri Hidjo. Hal tersebutt terlihat pada kutipan berikut ini.

“Aanneme!" Begitu Hidjo memanggail pelayan Belanda melayani tempat itu."

"Maneer!" Jawab pelayan dan dengan cepat datang mengampiri tempat Hidjo."

"Minta dua kopi!" Kata Hidjo kepada pelayan Belanda itu."

"Ya Maneer!" Jawab pelayan itu ramah" (Kartodikromo, 2010: 81).

Berdasarkan kutipan di atas, tokoh Hidjo dapat memerintah orang Belanda dengan mudah. Padahal bangsa Belanda saat itu sedang menjajah Hindia Belanda, justru Hidjo di Belanda dapat menyuruh mereka dengan sesuka hati. Hidjo di negeri Belanda juga sangat dihormati. Ini merupakan kritikan yang setidaknya dapat membuat kaum kolonial marah pada saat itu karena sebagaimana diketahui,kaum kolonial yang berada di Hindia Belanda memperlakukan kaum pribumi dengan tidak manusiawi, mereka berlagak menjadi penguasa, memerintah semaunya, dan lain sebagainya. Tampakny Marco Kartodikromo ingin menyadarkan pembacanya bahwa bangsa yang selama ini menjajah bangsanya, bukanlah bangsa yang harus dilayani terus-menerus. Kutipan di atas juga menggambarkan bagaimana rendahnya kaum kolonial diperlakukan oleh tokoh Hidjo.

Kritikan yang coba diungkapkan Marco Kartodikromo dan Abdoel Moeis tidak hanya diwakilkan oleh tokoh Hidjo dan Hanafi saja, melainkan beberapa tokoh di dalam kedua novel tersebut. Salah satunya adalah tokoh Controleur Walter dalam novel Student Hidjo dan Tuan de Bussee dalam novel Salah Asuhan. Kedua tokoh tersebut berasal dari kalangan bangsa kolonial. Tokoh Controleur Walter dan Tuan de Bussee merupakan tokoh yang memiliki rasa saling menghargai dan sangat menghormati kaum pribumi. Tokoh Controleur Walter dalam novel Student Hidjo merupakan warga negara Belanda yang sangat menghormati dan menghargai budaya Hindia Belanda, khususnya budaya Jawa. Sementara Tuan de Bussee merupakan pria berkebangsaan Eropa yang sangat menghargai orang-orang Bumiputra. Munculnya tokoh yang berasal dari bangsa kolonial yang menghargai keberadaan kaum pribumi menjadi pukulan yang cukup telak bagi bangsa kolonial pada saat itu. Marco Kartodikromo dan Abdoel Moeis juga ingin memperlihatkan bahwa orang Belanda (bangsa kolonial) 
tidak semuanya sombong atau jahat, melainkan masih ada dari mereka yang mau menghormati dan menghargai adat istiadat bangsa Hindia Belanda. Berdasarkan pernyataan di atas, kutipan yang menyatakan masing-masing karakterisik kedua tokoh tersebut terdapat pada kutipan berikut.

"Apa Tuan sudah menyelidiki bahwa adat istiadat orang Hindia ini sepuluh kali lebih sopan daripada adatnya orang Eropa kebanyakan?"(Kartodikromo, 2010: 117).

“... Semati Nyonya, yaitu seorang Bumiputra di Solok, yang sudah dikawininya di gereja, orang tua itu sudah mengganjur diri dari pergaulan orang banyak. Tiadalah ia pernah berkunjung ke rumah orang lain; barang siapa yang datang ke rumahnya, tiadalah ditolaknya, tapi sebagai sudah galibnya pada tabut orang Prancis, tiadalah pula ia kekurangan di dalam budi bahasa. ... (Moeis, 2010: 10).

Novel Student Hidjo merupakan novel yang menceritakan para intelektual pribumi yang lahir dari kalangan borjuis kecil. Hal tersebut digambarkan melalui tokoh Hidjo yang memiliki kecerdasaan dalam pendidikannya. Selain itu, novel ini juga memperlihatkan bagaimana perlakuan bangsa kolonial terhadap bangsa Hindia Belanda pada saat itu. Sementara, novel Salah Asuhan merupakan novel yang menceritakan percintaan antara dua remaja yang berbeda bangsa dan budaya. Perbedaan itu menimbulkan permasalahan di antara keduanya. Selain itu, novel ini juga menggambarkan perilaku atau gaya hidup seorang pemuda pribumi yang kebarat-baratan sehingga tokoh pemuda tersebut terkesan negatif. Namun dari kedua novel, setidaknya ditemui adanya 88 kritik terhadap bangsa kolonial pada saat itu, baik secara tersurat maupun tersirat.

\section{PENUTUP}

Dapat disimpulkan bahwa kritik yang ada di dalam novel Student Hidjo dan Salah Asuhan di antaranya adalah kritik untuk memperoleh pendidikan yang sederajat dengan para elite bangsawan, kritik mengenai perbedaan kebudayaan antara bangsa Barat dan Timur, kritik mengenai perlakuan yang dilakukan oleh bangsa kolonial, dan kritik perilaku yang dimiliki bangsa kolonial.

Tokoh pada kedua novel tersebut merepresentasikan masing-masing kebudayaan. Tokoh Hidjo dalam novel Student Hidjo merepresentasikan kebudayaan Timur. Hal ini dapat dilihat pada perilaku yang dijalani tokoh pada kesehariannya, seperti sopan, santun, menghormati kedua orang tua, dan lainlain. Sementara tokoh Hanafi dalam novel Salah Asuhan merepresentasikan kebudayaan Barat. Hal ini ditandai dengan gaya hidupnya yang kebarat-baratan. Tokoh Hanafi juga digambarkan sebagai tokoh yang memiliki perilaku pemarah dan keras kepala.

Penyampaian kritik yang terdapat pada kedua novel itu juga berbeda. Pada novel Student Hidjo kritik disampaikan dengan tersurat atau secara terang-terangan. Tidak heran jika novel ini termasuk ke dalam "Bacaan Liar". Sementara dalam novel Salah Asuhan penyampaian kritik terhadap bangsa kolonial disampaikan secara tersirat. Hal tersebut dikarenakan novel Salah Asuhan pertama kali diterbitkan oleh Balai Pustaka. Dalam menyiasati sensorsensor yang diberlakukan Balai Pustaka, Abdoel Moeis menyampaikan kritik secara tersembunyi melalui karyanya. 


\section{DAFTAR PUSTAKA}

Artawan, I Gede, and I Nyoman Yasa. 2015. "Mimikri Dan Stereotipe Kolonial Terhadap Budak Dalam Novel-Novel Balai Pustaka." Jurnal Ilmu Sosial dan Humaniora 4(1): 577-84.

Damono, Sapardi Djoko. 1979. Sosiologi Sebuah Pengantar Ringkas. Jakarta: Penelitian dan Pengembangan Bahasa Depdikbud.

- 2015. Sastra Bandingan. Tangerang Selatan: Editum.

Ernis, Poni. 2018. Perbandingan Karakter Tokoh Utama Novel Salah Asuhan Karya Abdoel Moeis dan Belenggu Karya Armijn Pane. Jurnal Pena Literasi Vol. 1, No. 1

Erowati, Rosida, and Ahmad Bahtiar. 2011. Sejarah Sastra Indonesia. Ciputat: Lembaga Penelitian UIN Syarif Hidayatullah Jakarta.

Haryanti, Novi Diah. 2011. Ide Antikolonialisme Tokoh-tokoh Perempuan dalam Tiga Karya Marco Kartodikromo: Suatu Tinjauan Pascakolonial. Universitas Negeri Jakarta.

Ismawati, Esti. 2013. Pengajaran Sastra. Yogyakarta: Ombak.

K.S, Yudiono. 2007. Pengantar Sejarah Sastra Indonesia. Jakarta: Grasindo.

Kartodikromo, Marco. 2010. Student Hidjo. Yogyakarta: Narasi.

Kasim, Razali. 1996. Sastra Bandingan Ruang Lingkup Dan Metode. Medan: USU Press.

Kosasih, E. 2008. Apresiasi Sastra Indonesia. Jakarta: Nobel Edumedia.
Mahattir, Nando Dzikir. 2020. "Struktur Kolonial Sebuah Relasi Dalam Novel Student Hidjo Karya Marco Kartodikromo." Humaniora Dan Era Disrupsi 1(1): 217-33.

Moeis, Abdoel. 2010. Salah Asuhan. 40th ed. Jakarta: Balai Pustaka.

Moleong, Lexy J. 2005. Metodologi Penelitian Kualitatif. Bandung: Remaja Rosdakarya.

Muhri. 2014. Sejarah Singkat Kesusasteraan Indonesia. Bangkalan: Yayasan Arraudlah.

Praptiwi, Rosita. 2014. "Kritik Sosial dalam Novel Surga Retak Karya Syahmedi Dean: Tinjauan Sosiologi Sastra dan Relevansinya sebagai Bahan Ajar Sastra Indonesia di SMA." Universitas Muhammadiyah Surakarta.

Ratna, Nyoman Kutha. 2013. Paradigma Sosiologi Sastra. Yogyakarta: Pustaka Pelajar.

Schmitt, MP, and A Viala. 1982. Savoire Lire. Paris: Didier.

Semi, M. Atar. 1993. Metode Penelitian Sastra. Bandung: Angkasa.

Sugihastuti, and Suharto. 2002. Kritik Sastra Feminis: Teori dan Aplikasinya. Yogyakarta: Pustaka Pelajar.

Sugiono. 2011. Metode Penelitian Kuantitatif, Kualitatif dan R\&D. 13th ed. Bandung: Alfabeta.

Sulton, Agus. 2015. "Sastra 'Bacaan Liar' Harapan Menuju Kemerdekaan." Jurnal Pendidikan Bahasa dan Sastra 15(2): 213.

Sumardjo, Jakob, and Saini K.M. 1997. Apresiasi Kesusastraan. Jakarta: 
Gramedia.

Taum, Yoseph Yapi. 2014. "Diskursus Batjaan Liar: Kajian Terhadap Dua Sastrawan Liar dalam Periode 19001933." Jurnal Penelitian 17(2): 13039.

Wijayanti, Sri H. 1989. Kawin Paksa dalam Novel Indonesia Salah Asuhan dan Novel Malaysia Mencari Istri: Sebuah Studi Perbandingan. Universitas Indonesia.

Wiyatmi. 2013. Konstruksi Nasionalisme dalam Novel-novel Indonesia Prakemerdekaan (Student Hijo Dan Salah Asuhan. Jurnal Kawistara Vol. 3 No. 2.

WS, Hasanuddin. 2009. Ensiklopedia Sastra Indonesia. Bandung: Titian Ilmu.

Yasa, I Nyoman. 2014. "Orientalisme, Perbudakan, dan Resistensi Pribumi Terhadap Kolonial dalam NovelNovel Terbitan Balai Pustaka." Jurnal Ilmu Sosial dan Humaniora 2(2): 249-56. 